\title{
Air Pollution Dispersion Modeling of Runway and Apron at Sam Ratulangi International Airport
}

\author{
Dewi Eviane ${ }^{1}$, Taufik Abdillah Natsir ${ }^{2}$, Nur Iswanto ${ }^{1}$, Zulfadly Urufi ${ }^{3}$, Mardjianto Adji ${ }^{1}$ \\ ${ }^{1}$ Graduate School, Master of Environmental Engineering, Institute of Technology Yogyakarta \\ ${ }^{2}$ Departmen of Chemistry, Faculty ofMathematics and Natural Science, Gadjah Mada University \\ ${ }^{3}$ Department of Urban and Regional Planning, Institut Teknologi Nasional Bandung, \\ Email: de.eviane@gmail.com
}

Received: May 05, 2021; Accepted: June 09,2021; Published: November 1,2021

\begin{abstract}
ABSTRCT
Air pollution generated from airport activities has become public concern and the subject of more rigorous government regulations. The Airport Operators are stipulated to control the pollution and for the accountability of air quality that might affect public health.The main objective of thisstudy is to establish a model for the distribution of air pollutants and to predict their concentrationsgenerated by the runway and apronoperationsat Sam Ratulangi International Airport (Manado)until 2024, in accordance with the airport expansion program. Thedata was collected in the airport surrounding area in 2018, while the climate data over a span of 10 years, from 2009 to 2018, was obtained from Sam Ratulangi Meteorological Station. Themodeling ondispersion of air pollutant gaseswas developed by the Gaussian Plume Equation. The simulation was performed using AERMOD software, and the results visualized by GIS software. AERMOD software was recommended by the US-EPA to predict the impact of air pollutants. The results predicted that the maximum concentrations of $\mathrm{NO}_{\mathrm{x}}$; $\mathrm{HC}$; and $\mathrm{CO}$ generated by runway activities modeling in 2024 were $250 \mu \mathrm{g} . \mathrm{m}^{-3} ; 6.4 \mu \mathrm{g} . \mathrm{m}^{-3}$; and $87 \mu \mathrm{g} . \mathrm{m}-3$ respectively. The results also predicted that the maximum concentrations of $\mathrm{NO}_{\mathrm{x}}$; CO; and $\mathrm{PM}_{10}$ due toapron operational activities in 2024 were $260 \mu \mathrm{g} . \mathrm{m}^{-3} ; 892 \mu \mathrm{g} . \mathrm{m}^{-3}$; and $2.5 \mu \mathrm{g} . \mathrm{m}^{-3}$ respectively. The model predicted that in 2024 the air pollution at Sam Ratulangi International Airport will remain under the limit as defined in Indonesian Government Regulation No. 22 of 2021. To mitigate the future increase in air emissions due to the increase in airport capacity, the recommendation were proposed in the several areas, which were including operation management, technology, policies and airport regulations, as well as the provision of green area.
\end{abstract}

Keywords: modeling, dispersion, pollutant

\begin{abstract}
ABSTRAK
Polusi udara yang dihasilkan dari kegiatan-kegiatan di bandara semakin menjadi perhatian masyarakat, dan menjadi subyek peraturan pemerintah yang semakin ketat. Operator Bandara diwajibkan untuk mengendalikan polusi yang timbul, serta bersikap terbuka terhadap kualitas udara yang mungkin dapat mempengaruhi kesehatan masyarakat. Tujuan utama dari penelitian ini adalah untuk membuat model bagi sebaran polutan udara dan memprakirakan konsentrasi polutan udara yang dihasilkan dari operasional landasan pacu dan apron di Bandar Udara Internasional Sam Ratulangi (Manado) sampai dengan tahun 2024 sesuai dengan program pemekaran bandara. Data dikumpulkan di area sekitar bandara pada tahun 2018, sedangkan data sekunder iklim dalam kurun waktu 10 tahun, dari tahun 2009 sampai dengan tahun 2018,diperoleh dari Stasiun Klimatologi Sam Ratulangi. Permodelan dispersi gas polutan udaradisusun menggunakan persamaan Gaussian Plume. Simulasi dilakukan dengan menggunakan perangkat lunak AERMOD dan visualisasi hasil menggunakan perangkat lunak GIS. AERMOD yang merupakan perangkat lunak yang direkomendasikan oleh US-EPA untuk memprediksi dampak polutan udara. Hasil permodelan kegiatan operasional landasan pacu pada tahun 2024 memprediksi konsentrasimaksimum $\mathrm{NO}_{x}$; HC; dan CO masing-masing adalah $250 \mu \mathrm{g} \cdot \mathrm{m}^{-3} ; 6,4 \mu \mathrm{g} \cdot \mathrm{m}^{-3}$; dan $87 \mu \mathrm{g} \cdot \mathrm{m}^{-3}$. Hasil permodelan juga memprediksi konsentrasi maksimumNO ${ }_{x}$; CO; dan $\mathrm{PM}_{10}$ sebesar $260 \mu \mathrm{g} . \mathrm{m}^{-3} ; 892 \mu \mathrm{g} . \mathrm{m}^{-3}$; dan $2.5 \mu \mathrm{g} . \mathrm{m}^{-3}$ yang dihasilkan dari kegiatan apron pada tahun 2024. Hasil permodelan memprediksi bahwa di tahun 2024 polusi udara di Bandar Udara Internasional Sam Ratulangi masih berada di bawah ambang batas yang ditetapkan dalam Peraturan Pemerintah Indonesia No. 22 tahun 2020. Guna memitigasi peningkatan emisi udara akibat dari
\end{abstract}


peningkatan kapasitas bandara, beberapa rekomendasi telah diajukan di beberapa bidang, seperti di bidang manajemen operasi, teknologi, kebijakan dan regulasi, serta penyediaan area hijau.

Kata Kunci: permodelan, dispersi, polutan

\section{INTRODUCTION}

Transportation is an economic supporting sector which has grown very rapidly in recent years.One of the transportation sectors that has been experiencing rapid development is the aviationindustry, which is designated by capacity development and increase in the number of airports. The increasing in capacity as well as the number of airports will therefore increase the consumption of aircraft fuel and supporting transportation in airport operations. These will obviously intensify air pollutants quantities. The contribution of the aviation sector to air emissions is estimated of up to $5 \%$ of total air emissions[1].

On the other hand, climate change has become more public issue and awareness. Government regulations on environment protection, particularly in reduction of Green House Gas (GHG) emissions, are eminent. Thereforeair pollution due to airport activities is under public and government scrutinizing. The airport operators are stipulated to control the pollution. The accountability of air quality that might affect public health and wellbeing is expected.

There were several researches to study the impact of aircraft emissions on air quality around the airport area. Some of the chemical compounds that have significant impact on air quality include nitrogen oxides $\left(\mathrm{NO}_{\mathrm{x}}\right)$, particles $\left(\mathrm{PM}_{10}, \mathrm{PM}_{2.5}\right)$, hydrocarbons (HC), and carbon monoxide (CO) [2]. Further, particle size distribution is very dependent on airport activities[3]. $\mathrm{NO}_{\mathrm{x}}$ measurements at London Heathrow Airport showedthe quantity of aircraft emission depends on engine age, whereas the larger aircraft sizes, the higher particle nucleation. $\mathrm{NO}_{\mathrm{x}}$ emission measurements carried out at Tbilisi International Airport (Georgia) demonstrated that $\mathrm{NO}_{\mathrm{x}}$ generated during take-off and climb-out mode contributed $27 \%$ and $37 \%$ of total emissions, while $\mathrm{CO}$ and $\mathrm{HC}$ generated when the taxi mode in the runway area contributed to $77 \%$ and $70 \%$ of total emissions [4]. Measurements at Beijing International Airport showedthat $\mathrm{NO}_{\mathrm{x}}$ generated during takeoff and climb out mode were $20.5 \%$ and $55.5 \%$ of total emissions, while $\mathrm{CO}_{2}$ and $\mathrm{HC}$ emissions generated during the taxi phase were $91.6 \%$ and $92.2 \%$ of the total emissions. The annual measurement results for $\mathrm{NO}_{\mathrm{x}}$, $\mathrm{CO}$, VOCs, $\mathrm{SO}_{2}$, and $\mathrm{PM}_{2.5}$ compounds were $8.76 \times 10^{3}, 4.43 \times 10^{3} ; 5.43 \times 10^{2} ; 4.80 \times 10^{2}$, and $1.49 \times 10^{2}$ ton/yearrespectively[5].

One of the softwares widely employed to predict the air quality is the American Meteorological Society/Environmental Policy Agency Regulatory Model (AERMOD). Thismodeling software based on the Gaussian Plume model theory recommended by the US EPA [6], and has been commonly used toanalyse the emissionsgenerated by aviation sources such as airplanes, auxiliary power units, and ground support equipments. A researchat Ataturk International Airport, Turkish, had been carried out using the AERMOD model[7] to study the airport activitiesthat had effect on the spread of $\mathrm{NO}_{\mathrm{x}}$, $\mathrm{CO}$, and $\mathrm{HC}$ during a period of one year. The results concluded that aircraft emissions led to increasing in annual $\mathrm{NO}_{\mathrm{x}}$ in the airport. The research also included theinvestigation on the dispersion of gas emissions generated by aircraft activities using AERMOD modeled on inert chemicalsfor one year period of time. The simulation showed that the take-off phase was responsible for the increasingin $\mathrm{NO}_{\mathrm{x}}, \mathrm{SO}_{2}$, and $\mathrm{PM}_{10}$ emissions. However, the increase in concentration beyond the threshold of the European Union Directive 2008/50 / EC only occurred for $\mathrm{NO}_{\mathrm{x}}$ emissions.

The AERMOD dispersion code combined with the EDMS emission scenario capable to provide an initial assessment of the airport's impact on air quality [8]. Dispersion modeling of gas and particulate emissions from aircraft activity at Chania Airport (Greece) had also been performed using AERMOD [9], and demonstrated that $\mathrm{NO}_{\mathrm{x}}$ concentrations also exceeded the limits permitted by the European Union regulations. However, the contribution of the aircraft takeoff and landing cycle to the ground level of CO, $\mathrm{SO}_{2}$, and $\mathrm{PM}_{2.5}$ concentrations were below the air quality threshold values.

The purpose of this study was to develop the model for the dispersion of pollutants generated by aviation activities at Sam Ratulangi International Airport using AERMOD software. AERMOD air pollutant modeling was selected because the softwareis very robust and it has already widely used in Indonesia to support the airport zoning management and policy. According to the Airport Council International version[10], the airport was the second largest airport in Sulawesi,and the 18th busiest airport in Indonesia. Apparently, there has beensignificantincreaseinSam Ratulangi International Airport activities. To anticipate the trend, the airport authority had set the program to expand itscapacity in 2024. Therefore, it was compulsory to analyse and to predict the air emissions in this airport. 


\section{RESEARCH METHOD}

The research location was at Sam Ratulangi International Airport, Manado City, North Sulawesi, andFigure 1. shows the map of the airport. This simulation was using Gaussian air dispersion modeling, and the instrumentsemployedwere including: laptop, AERMOD software released by the US EPA, GIS to visualize the results of AERMOD, and WRPLOT View from Lakes Environmental to describe wind flowers. The data onwind direction and speed for the period of 2009 to 2018 was obtained from the Sam Ratulangi Meteorological Station. Data on the number and the type of vehicles operating at the airportwasprovidedby PT Angkasa Pura 1. The transportation data was used to predict the changes in pollutant concentrations due to the airport capacity expansion program.

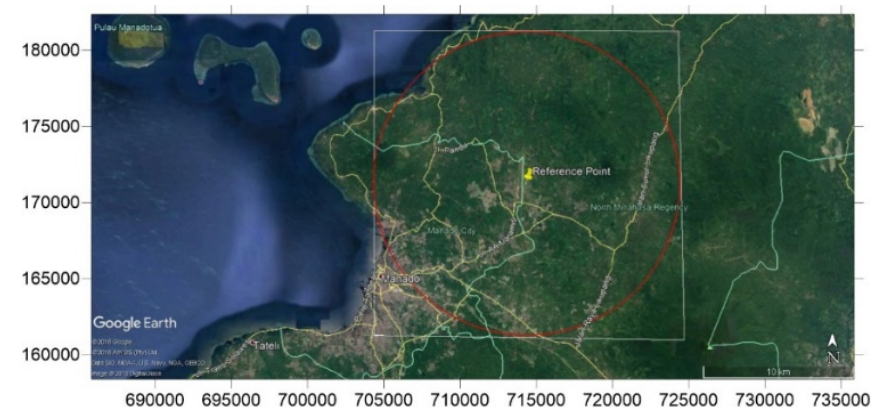

Figure 1. Location map of of Sam Ratulangi International Airport in Manado, North Sulawesi.

Air dispersion modeling was carried out using several inputs: meteorological data, emissiongenerating equipment data, elevation data, and area maps. Meteorological dataconsists of Surface Data in the formats of sfcfile andthe Profile Data inpflfile. Surface Data file consists of sensible heat flux, surface friction velocity, convective velocity scale, vertical potential temperature gradient above PBL, convective mixing height, mechanical mixing height, Monin-Obukhov length, surface roughness, Bowen's ratio, Albedo. While the Profile Data file consists of wind speed, wind direction, reference wind altitude (WRef = $10 \mathrm{~m}$ ), temperature, reference temperature altitude (TRef $=2 \mathrm{~m}$ ), rainfall code, rainfall, and humidity. The range of climate data values is presented in Table 1. Meteorological data was processed using AERMET which is already available in AERMOD. Terrain data was obtained from the GTOPO30 available online at http://www.src.com, which was then processed using AERMAP. The wind rose image wasvisualized by employing WRPLOT View software. Figure 2 presents the workflow of AERMOD software.

Table 1. The range of climate data values

\begin{tabular}{lcc}
\hline Data & Range of value & Unit \\
\hline Cloud cover & $0-10$ & tenth \\
\hline Air temperature & $-70-60$ & ${ }^{0} \mathrm{C}$ \\
\hline Air humidity & $0-100$ & $\%$ \\
\hline Air pressure & $700-1100$ & $\mathrm{mb}$ \\
\hline Wind direction & $0-360$ & degree \\
\hline Wind velocity & $0-99$ & $\mathrm{m.s}^{-1}$ \\
\hline Cloud height & $0-30450$ & $\mathrm{~m}$ \\
\hline Rainfall & $0-1000$ & $\mathrm{~mm}^{-2}$ \\
\hline Solar radiation & $0-14.5$ & $\mathrm{whm}^{-2}$ \\
\hline
\end{tabular}




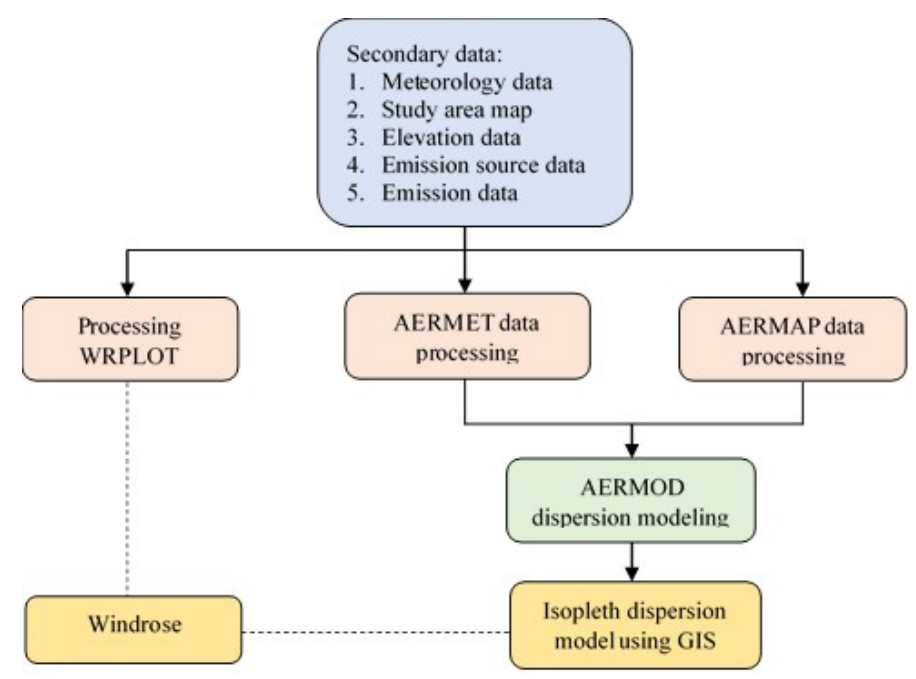

Figure 2. Workflow of AERMOD software [11].

\section{RESULT AND DISCUSSION}

\subsection{Wind Direction}

The wind speed over the period of 2009 to 2018 was in the rangeof $0.8-13 \mathrm{~m} / \mathrm{s}$, and classified as fresh wind to strong wind.The direction was mainly towards the north. Figure 3. shows the wind rose based on the average wind speed and wind direction during that period. The current dominant wind direction was in good suitability. This comparison was based on the position of the airport runway against the level of suitability of the surface wind direction. Takeoff or landing at Sam Ratulangi International Airport will be hampered if there is a large wind coming from the east [12].

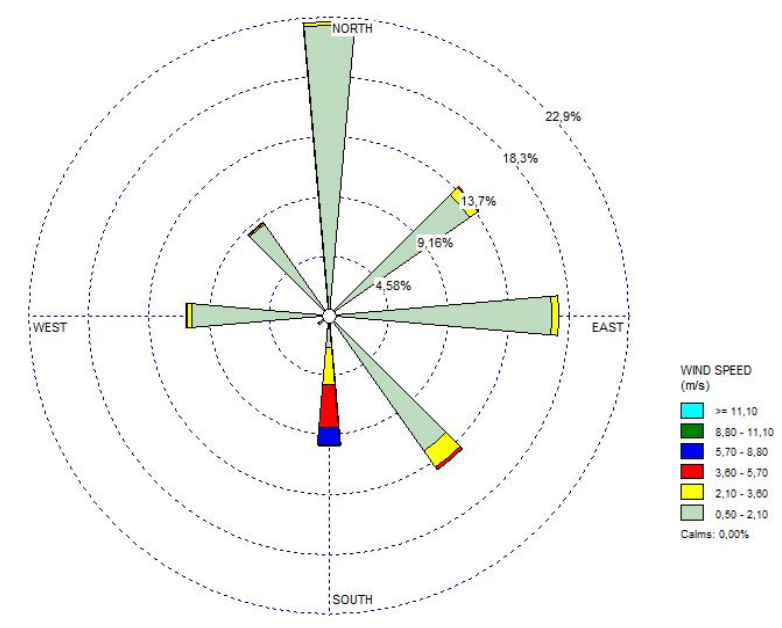

Figure 3. Windrose at the Sam Ratulangi Meteorological Station for the Period of January-December from 2009-2018.

\subsection{Prediction of Air Pollution Due to RunwayActivities}

The concentrations of air pollutants generated by runway operations are influenced by the number of movement and the types of aircraft. There was an increase in aircraft movements based on the performance data of PT Angkasa Pura 1 at Sam Ratulangi Airport. The movement was 19,773in 2013, and 27,594 in 2017 , or an average increase of $9.9 \%$ per year over the period of 4 years. Table 2 is tabulating the forecast of aircraft movements at theairport in 2022 to 2024 based on the movement data from 2013 to 2017. The main aircraft type that operates at Sam Ratulangi Airport is Airbus A320-300, with the CF6-80E1A2 turbo jet engine. Table 3presents the emission factors of the Airbus A320-300 aircraft with the CF6-80E1A2 turbo jet engine type[13]. Table 4. demonstrates the pollutant emission values calculated using the LTO emission calculator for Sam Ratulangi airport in 2022-2024. 
Air Pollution Dispersion Modeling of Runway and Apron at Sam Ratulangi International Airport

Table 2. Forecast of aircraft movements at Sam Ratulangi Airport in 2022-2024

\begin{tabular}{lccc}
\hline Year & Aircraft movement/year & Aircraft movement/day & Aircraft movement/hour \\
\hline 2013 & 19773 & 54.17 & 3.2 \\
\hline 2014 & 19198 & 52.60 & 3.1 \\
\hline 2015 & 20841 & 57.10 & 3.4 \\
\hline 2016 & 26363 & 72.23 & 4.2 \\
\hline 2017 & 27594 & 75.60 & 4.4 \\
\hline Estimated increase in the number of aircraft $(+9,9 \% /$ year $) *$ & 5.8 \\
\hline 2022 & 35932 & 98.44 & 6.3 \\
\hline 2023 & 39238 & 107.50 & 6.9 \\
\hline 2024 & 42848 & 117.39 & \\
\hline
\end{tabular}

Table 3. Emission factor for A 320-300 aircraft with engine type CF6-80E1A2 turbo jet from ICAO (International Civil Aviation Organization)

\begin{tabular}{ccccc}
\hline & \multicolumn{4}{c}{ Engine thrust setting (\% of maximum thrust) } \\
\cline { 2 - 5 } & 7 & 30 & 85 & 100 \\
\hline $\begin{array}{c}\text { Rate of fuel burn } \\
\text { (kg/s/engine) }\end{array}$ & 0.2280 & 0.7240 & 2.245 & 2.767 \\
\hline $\begin{array}{c}\text { Rate of emission of CO } \\
\text { (kg/s/engine) }\end{array}$ & 0.003960 & 0.001339 & 0.00008980 & 0.0001384 \\
\hline $\begin{array}{c}\text { Rate of emission of HC } \\
\text { (kg/s/engine) }\end{array}$ & 0.0002850 & 0.00007964 & 0.00008980 & 0.0001107 \\
\hline $\begin{array}{c}\text { Rate of emission of } \mathrm{NO}_{\mathrm{X}} \\
\text { (kg/s/engine) }\end{array}$ & 0.001113 & 0.009166 & 0.04941 & 0.07947 \\
\hline
\end{tabular}

Table4. Emissions of aircraft pollutants

\begin{tabular}{ccccc}
\hline \multirow{2}{*}{ Emission } & \multirow{2}{*}{ Unit } & Departure & Arrival & Total \\
\hline $\mathrm{CO}$ & $\mathrm{kg}$ & 5.673 & 3.209 & 8.882 \\
\hline $\mathrm{HC}$ & $\mathrm{kg}$ & 0.439 & 0.223 & 0.662 \\
\hline $\mathrm{NO}_{\mathrm{x}}$ & $\mathrm{kg}$ & 21.304 & 5.121 & 26.425 \\
\hline
\end{tabular}

Figure 3a presents the results of $\mathrm{NO}_{\mathrm{x}}$ pollutant dispersion modeling in 2024 generated by runway operations. The maximum concentration of $\mathrm{NO}_{\mathrm{x}}$ was predicted to increase by $250 \mu \mathrm{g} . \mathrm{m}^{-3}$ in 2024 . This based on the assumption of an increase in the number of aircraft movements of $9.9 \%$ each year. Figure $3 \mathrm{~b}$. shows that the HC concentration in 2024 was predicted to increase by $6.4 \mu \mathrm{g} . \mathrm{m}^{-3}$. Figure 3c. shows the CO concentration of in 2024 was predicted to increase by $87 \mu \mathrm{g} \cdot \mathrm{m}^{-3}$.

(a)

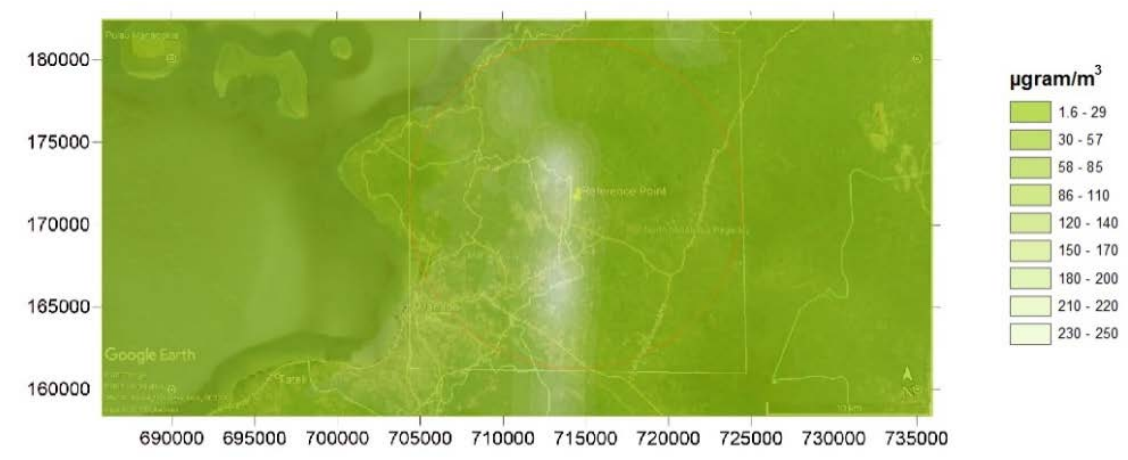


(b)
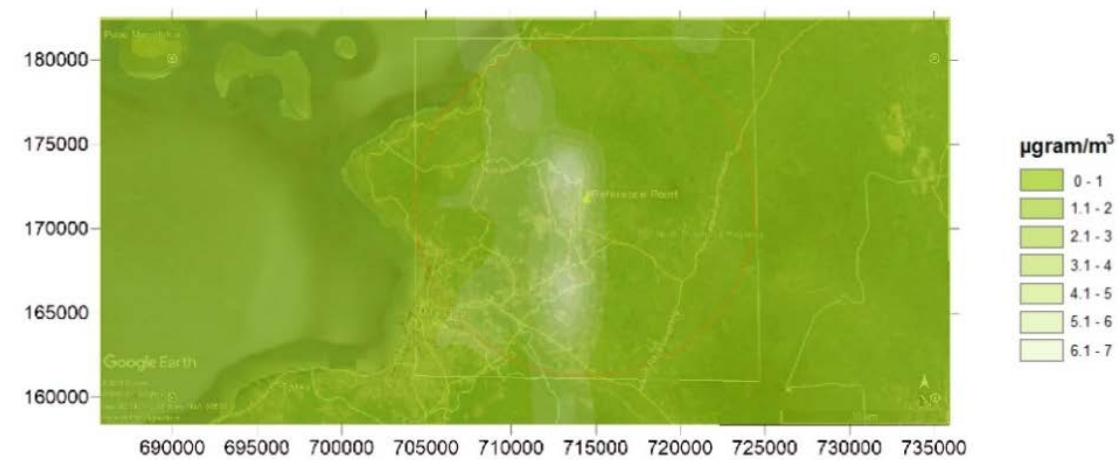

(c)

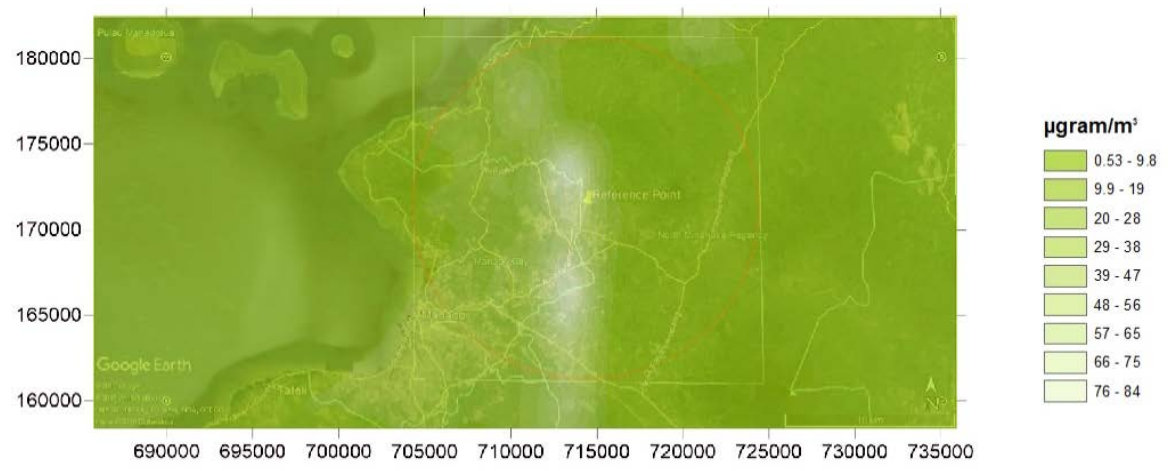

Figure 3. Modeling of pollutant (a) NOx, (b) HC, and (CO) due to runway operations in 2024.

\subsection{Prediction of Air Pollution Due toApron Activities}

Air pollutants generated by apron operations are influenced by the number and vehicletypes of supporting ground facilities. Table 5presents the emission of aircraft ground handling factors referring to the Environmental Impact Assessment (EIA) document for the New Yogyakarta International Airport (NYIA).The EIA NYIA airport document was used as the reference in determining the value of the emission factor for Sam Ratulangi Airport because the two airports, Sam Ratulangi International Airport and NYIA, will employ the similar types of aircraft ground handlings.

Table5. Factor emission of aircraft ground handling

\begin{tabular}{lcccc}
\hline Aircraft ground handling & Amount & $\mathrm{CO}\left(\mathrm{g} . \mathrm{s}^{-1}\right)$ & $\mathrm{NO}_{\mathrm{x}}\left(\mathrm{g} \cdot \mathrm{s}^{-1}\right)$ & $\mathrm{PM}\left(\mathrm{g} . \mathrm{s}^{-1}\right)$ \\
\hline Mobile air starter & 1 & 0.63 & 0.16 & 1.15 \\
\hline Passanger stairs & 1 & 0.27 & 0.07 & 0.50 \\
\hline Passanger bus & 2 & 0.83 & 0.22 & 1.53 \\
\hline Crew bus & 2 & 0.75 & 0.20 & 1.38 \\
\hline Cargo loader & 1 & 0.26 & 0.07 & 0.48 \\
\hline Catering truck & 2 & 0.49 & 0.13 & 0.90 \\
\hline Water truck & 2 & 0.98 & 0.25 & 1.79 \\
\hline Lavatory truck & 2 & 0.98 & 0.25 & 1.79 \\
\hline Refueling disperser & 2 & 1.83 & 0.48 & 3.37 \\
\hline GA refueling truck & 2 & 2.64 & 0.69 & 4.86 \\
\hline Line maintance truck & 2 & 1.00 & 0.26 & 1.84 \\
\hline Cargo container tractor & 2 & 0.50 & 0.13 & 0.92 \\
\hline Car & 2 & 1.00 & 0.26 & 1.84 \\
\hline Large aircraft & 6 & 0.40 & 0.89 & 0.05 \\
\hline TOTAL & & 12.55 & 4.05 & 22.41 \\
\hline
\end{tabular}

The AERMOD simulation predicted an increase in the peak concentration of $\mathrm{NO}_{\mathrm{x}}$ dispersion by approximately $260 \mu \mathrm{g} . \mathrm{m}^{-3}$. The simulation also predicted the highestof CO parameters by $892 \mu \mathrm{g} . \mathrm{m}^{-3}$, while the $\mathrm{PM}_{10}$ dispersion is predicted to increase in the highest concentration of $2.5 \mu \mathrm{g} . \mathrm{m}^{-3}$. Figure 4 . presents the modeling of pollutants (a) $\mathrm{NO}_{\mathrm{x}}$, (b) CO, and (c) $\mathrm{PM}_{10}$ originated by apron operations in 2024 . 

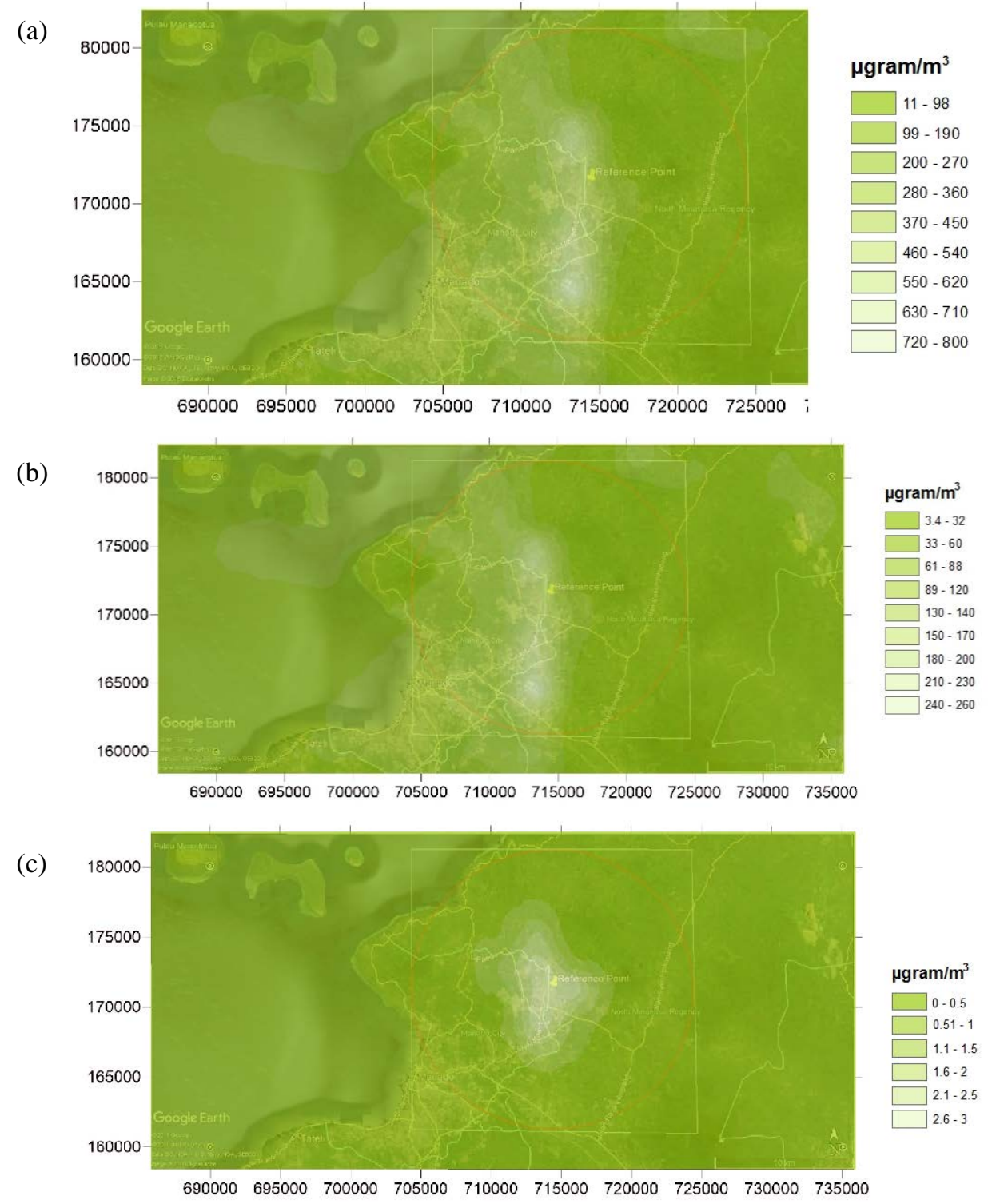

Figure 4. Modeling of pollutants (a) NOx, (b) CO, and (c) PM $_{10}$ due to apron operations in 2024.

\subsection{Implications of The Modeling Results}

Based on the modeling results, the concentration of pollutants generated by apron activity was slightly higher than the emission due to runway operations. It was predicted that the concentration of pollutants willnonetheless below the limits for ambient air lice as outlined in Indonesian government Regulation No. 22 of 2021. However, there is still possibility of the differences in the results of concentration measurements in the field and the predictionsfrom modeling.

Various strategies to reduce airpollution from the aviation industry could be implemented, including: better operation management, the use of improvedtechnologies, developing policies that in accordancewith airport regulations, and the provision of green area. In airport operation, the prolonged idle engine during aircraft preparation before being pushed back and the extended runway queueing should be avoided. The lengthy idle engine mode is clearly causing more exhaust gas emission from the aircraft engine.

The ageing aircrafts have lower fuel efficiency leading to more fuel consumption, and in consequent more gas emissions. This is obviously beyond the airport authorities capability to manage or to control. However, there are several better technology alternatives to reduce gas emissions in place. The option to use hybrid or electric vehicles in various ground operations could be under consideration. The vehicles operated in airport daily operations are the considerably source of gas emissions. Hybrid or further electric vehicles could reduce the emission significantly. There are various types and models to replace internal combustion vehicles available in the market.This option understandably requires a significant financial investment. 
However, the use of electric cars and carts in airport area, particularly in the terminal area, will reduce gas emissions as well as will improve public health and comfort.

Several policies that support emission reduction include continuously improving flight operational procedures,better air traffic control and better flight arrangements.Regulation of the aviation operational safety area as a form of city space control to limit activities that will disrupt the airport has been stipulated in the Manado City Spatial Plan which is mentioned in Perda No. 1/2014. The results of this modeling can be used as a reference for technical regulations, which support the policy Aviation Operational Safety Area. In addition, this study could also be a reference for policy framework in determining thegreen open space. As stipulated by local government, of at least $30 \%$ should be providedby the airport as green open space in order to reduce gas emission impacts tothe city of Manado surrounding area. Green open area plots in roadside areas could effectively reduce CO concentrations by $8.5 \%$ compared to open plots[14]. In this study, there was a compelling correlation between wind and $\mathrm{CO}$ concentration. Vegetation could withstand the movement of the wind so that it can trap and absorb pollution.

As the significant economic growth, the rapid increase in the number of passengers and cargo transported by aircraft is inevitable. Therefore, the airport authorities regularly need to expands airport facilities.The infrastructure development must take into account the necessity to maintain adequate green area. This is to keepthe pressure on environment caused by airport activities is manageable. Further, the strategic and integrated approach with local development plan should also in place. Failure to control the development of residential area or other infrastructures in airport site and immediate surrounding area, for instance, will create many unpredictable and serious problems. The problems that will not only affect airport operation, but also society in general perspective. Therefore maintaining sufficient green area for environment purposes as well as to prevent social and political issues in the future is very critical for the sustainable airport operation.

\section{CONCLUSIONS}

From the previous studies and from the modeling, it was found that the increase or decrease in the concentration of air pollutants generated by the runway activities was greatly influenced by the aircraft movements, while the emission generated in apron for ground handling activities was determined by the types and the numbers of vehicles used.

With the average increase of 9,9\% annually, the AERMOD modeling predicted that up to 2024, air pollution in Sam Ratulangi International Airport will remain below the limitsas outlined in Indonesian government Regulation No. 22 of 2021. However, to mitigate the increase in gas emissions due to the future growth in runway and ground activities, several recommendations have been proposed. These were including better operation management, implementadvanced technologies, continuous review and improve in the policies that related to airport regulations, and the provision of green area.

\section{ACKNOWLEDGEMENT}

The author very much appreciates the support by the PT Sucofindo and PT Angkasa Pura I as fund provider as well as research partners.

\section{REFERENCES}

[1] E. Terrenoire, D. A. Hauglustaine, T. Gasser, and O. Penanhoat, "The Contribution of Carbon Dioxide Emissions from the Aviation Sector to Future Climate Change,” Environ.Res. lett, vol. 14, 2019.

[2] O. Zaporozhets and K. Synylo, "Modeling of Air Pollution at Airports," InteechOPen, 2019.

[3] B. Stacey, R. M. Harrison, and F. D. Pope, "Evaluation of Aircraft Emissions at London Heathrow Airport," Atmos. Environ., 2021.

[4] A. Tokuslu, "Estimation of Aircraft Emissions at Georgian International Airport,” Energy, vol. 206, pp. 1-7, 2020.

[5] X. Yang, S. Cheng, J. Lang, R. Xu, and Z. Lv, "Characterization of Aircraft Emissions and Air Quality Impacts of an International Airport,” J.of Environ. Sci., vol. 72, pp. 198-207, 2018.

[6] A. Kumar, R. S. Patil, A. K. Dikshit, and R. Kumar, "Application of AERMOD for Short Term Air Quality Prediction with Forecasted Meteorology using WRF Model,” Clean Technol. Environ. Policy, 2017.

[7] S. L. Kuzu, "Estimation and Dispersion Modeling of Landing and Take-off ( LTO ) Cycle Emissions from Atatürk International Airport,” Air Qual Atmos Heal., 2017.

[8] I. Simonetti, S. Maltagliati, and G. Manfrida, "Air Quality Impact of a Middle Size Airport Within an Urban Context through EDMS Simulation,” Transp. Res. Part D, vol. 40, pp. 144-154, 2015.

[9] M. Makridis and M. Lazaridis, "Dispersion Modeling of Gaseous and Particulate Matter Emissions from 
Air Pollution Dispersion Modeling of Runway and Apron at Sam Ratulangi International Airport

Aircraft Activity at Chania Airport, Greece,” Air Qual. Atmos. Heal., no. 2017, 2019.

[10] A. Andre et al., “Analisis Kapasitas dan Optimalisasi Apron Sam Ratulangi Manado,” J. Sipil Statik, vol. 8, no. 2, pp. 175-182, 2020.

[11] T. A. Natsir et al., "Using Aermod to Simulation Study of Carbon Monoxide Pollution Effect in Yogyakarta City Caused by The Emission of Motor Vehicles,” J. Mns. Lingkung., vol. 24, no. 1, pp. 11-16, 2017.

[12] D. Tulandi, J. Tumangkeng, and F. Tumbelaka, “Analisis Data Angin Permukaan di Bandara Sam Ratulangi Manado Menggunakan Metode Wind Rose,” JSME (Jurnal Sains, Mat. dan Edukasi), vol. 1, pp. 11-16, 2020.

[13] M. Winther et al., "EMEP/EEA Air Pollutant Emission Inventory Guidebook 2016,” 2017.

[14] A. N. Izzah, N. Nasrullah, and B. Sulistyantara, "Efektivitas Jalur Hijau Jalan dalam Mengurangi Polutan Gas CO (The Effectivity of Roadside Green Belt in Reducing the Concentration of CO Gas Pollutant )," J. Ilmu Pertan. Indones., vol. 24, no. 4, pp. 337-342, 2019. 
